\title{
An Exploration of Antecedents and Consequences of Brand Attachment among a Cross Section of Malaysian Consumers
}

\author{
Andrew Lee Hock Cheong ${ }^{1}$ \\ ${ }^{1}$ Taylor's Business School, Taylor's University, Kuala Lumpur, Malaysia \\ Correspondence: Andrew Lee Hock Cheong, Taylor's Business School, Taylor's University, Lakeside Campus, \\ No.1, Jalan Taylor's, 47500 Subang Jaya, Selangor, Malaysia. Tel: 60-3-5629-5690. E-mail: \\ lee.hockcheong@taylors.edu.my
}

\author{
Received: February 5, 2013 Accepted: March 7, 2013 Online Published: April 27, 2013 \\ doi:10.5539/ass.v9n5p263 URL: http://dx.doi.org/10.5539/ass.v9n5p263
}

\begin{abstract}
This article discusses the findings of an explorative study which identified the antecedents of brand attachment and its consequences among a small cross section of selected Malaysian consumers. The findings provide some deeper insights on brand attachment, as unlike previous studies this study elicited responses not only from goods brands, but also service brands. Additionally, this research not only gained insight on the antecedents of brand attachment among a small selected cross section of Malaysian consumers but also importantly addressed its consequences. In-depth interviews were conducted and four major antecedents of brand attachment emerged, namely achieving self and social goals, strong product and service characteristics, positive reminiscence and consumer expectations. Six consequences of attachment to brands were identified and these included commitment, sacrifice for the brand, brand advocacy, competing brands are ranked second, automatic brand recollection and disappointment and discontentment.
\end{abstract}

Keywords: brand attachment, in-depth interviews, lived experiences, goods brands, service brands

\section{Introduction}

Consumers are surrounded by brands daily. Brands have become part of our lives. We grow in and out of love with some brands. Some consumers may use a brand only once, never to touch it again due to reasons such as poor quality, lack of functionality, overly priced or simply a bad experience with the brand. However, for some consumers, they remain fond of a particular brand. They are willing to stay with a brand at all cost. Repeat purchases of the same brand are made over a long period of time. These consumers are strong advocates of the brands that they are emotionally attached to.

It is important for marketers to understand the reasons for consumers to be attached towards a particular brand in order to develop a strategy to build, retain and strengthen this attachment. Consumers who are emotionally attached (Berman \& Sperling, 1994) to a brand can be the brand's unofficial ambassador. These consumers are supportive and promote the brand via positive word-of-mouth. Thus, understanding the antecedents will enable marketers to build a strong foundation for consumers to develop a positive relationship from their initial contact with the brand. Consequently, the effects of brand attachment also needs careful investigation as it impacts marketing efforts put in by the brand itself and competing brands.

The explorative study discussed in this paper aimed to contribute to the growing literature on brand attachment and also the scarcity of studies pertaining to Malaysian consumers' attachment toward brands and its consequences. Furthermore, Grisaffe and Nguyen (2011) emphasized that service brand attachment merit further investigation. Thus, the study also investigated consumers' attachment toward service brands. The review of current literature revealed that existing studies specifically in the Malaysian context have yet to address Malaysian consumers' attachment towards brand.

\section{Brand Attachment Construct}

The brand attachment construct draws its origin from the attachment theory. The attachment theory is the work of Ainsworth and Bowlby (1991). Drawing on concepts from ethology, cybernetics, information processing, developmental psychology, and psychoanalysts, John Bowlby formulated the basic tenets of the theory. He revolutionized the thinking about a child's ties to the mother and its disruption through separation, deprivation, 
and bereavement. Grisaffe and Nguyen (2011) posited that in the context of brands, emotional attachment implies a strong desire to maintain the security felt in connection with a brand and to actively avoid separation. Separation avoidance is manifested through emotionally rooted repurchase and switching avoidance.

Thomson, MacInnis and Park (2005) defined emotional attachment to brands as an emotion-laden bond between a person and a brand characterized by deep feelings of connection, affection and passion. Building on the attachment theory, their quantitative study offered reliability and validity of the conceptualization and operationalization of this construct. Emotional brand attachment from their findings showed discriminant validity with other constructs like brand attitudes, brand satisfaction and brand involvement. Their study developed a 10-item scale to measure brand attachment.

Brand attachment was also defined by Park, MacInnis and Priester (2006a) as the strength of the cognitive and affective bond connecting the brand with the self. They further elaborated that attachment denotes a psychological state of mind in which this bond connects a brand with an individual in a way that the brand is viewed as an extension of the self.

\section{Literature Review}

Prior to the works of Thomson et al. (2005), various brand relationship studies have been conducted. Notable among them is the exploratory brand relationship study by Fournier (1998). She found that consumers were involved in relationships with a collective number of brands to benefit from the meaning that these brands add into their lives. The meaning that they experienced was functional and utilitarian or more psychosocial and emotional in nature. Her work was further expanded by Escalas (2004) who explained that the meaning of a brand is often the result of it being part of a story. Using the narrative meaning-making process, Escalas (2004) found that some brands became more important and valuable than others to consumers. These brands became connected to consumers' sense of self. On the other hand, by using an interpretive approach to understanding the role of nostalgia in the consumption experience, Holbrook and Schindler (2003) found that respondents were attached to a particular brand of tools/gadgets because these are frequently used in their trade. The disc jockey and runner formed strong nostalgic bonds with gadgets like the Vestex music mixing device and Timex watch respectively as they spent countless hours with these brands.

Instead of studying the individual consumer per se, Veloustou and Moutinho (2009) extended the study on brand relationship by researching on brand communities. They concluded that brand communities are a better predictor of the strength of brand relationships than the long term brand reputation itself. They explained that a brand community is a community of individuals formed as a result of their attachment to a product or a brand. The individuals in a brand community share the knowledge that they have regarding a brand's quality and other positive aspects of the brand.

Since the seminal studies by Thomson et al. (2005), studies on brand attachment have been on the rise in recent years. These studies are mainly quantitative in nature. Research examining Chinese telecommunications customers by Lai, Griffin and Babin (2009) concluded that service quality affects both satisfaction and loyalty indirectly. Service quality is crucial to improving value and image, which determine service satisfaction and loyalty. Service satisfaction and loyalty in turn forms the basis of attachment. The brand attachment literature is further expanded by the study of Lambert-Pandraud, and Laurent (2010) which involved older consumers in comparison to Thomson et al.'s study (2005) where student samples were the main respondents. Their studies concluded that older consumers exhibited a propensity to remain attached for a longer duration to the same preferred brand of perfume. In another study on older consumers by Jahn, Gaus and Kiessling (2012), they found that the older elderly (i.e. aged above 65 years) were more emotionally attached to their coffee brands than the younger elderly consumers (i.e. those between 50 and 65 years old). For the older elderly consumers their coffee brand attachment is influenced by what the brand does as a caring relationship partner. On the other hand, brand trust determines the younger elderly's brand attachment.

Subsequently, Park, MacInnis, Priester, Eisingerich and Iacobucci (2010) developed and compared their brand attachment measure with Thomson et al. (2005). They argued that attachment is more than the three emotional components of affection, passion and connection as espoused by Thomson et al. (2005). Brand attachment according to them is also reflected by mental representations that involve brand-self cognition, thoughts and autobiographical brand memories that may not be captured by emotions. Drawing from the self-expansion theory, Park et al. (2010) developed a parsimonious measure of brand attachment using an 8-item scale on the basis of brand-self connection and brand prominence. Their research among undergraduate students also revealed that more strongly consumers are attached to a brand, the more willing they are to forgo their personal resources to maintain that relationship. 
Arising from a dearth of qualitative research in the area of brand attachment and more specifically the lack of studies on its antecedents, Grisaffe and Nguyen (2011) embarked on a grounded theory approach in studying brand attachment antecedents. Their qualitative study among 579 American university students and their acquaintances derived five primary antecedents of emotional attachments to brands which are superior marketing characteristics, traditional customer outcome states, unique user-derived benefits, socialization forces and sentimentality/emotional memory. They concluded that these antecedents possess varying degrees of marketer controllability. Grisaffe and Nguyen's (2011) reliance on a relatively large random sample instead of a purposeful sample may have resulted in a less rigorous technique being used. Marshall (1996) argued that studying a random sample is not effective in understanding complex issues relating to human behavior such as brand attachment. He further added that samples for qualitative studies tend to be small.

In this exploratory study, non-student participants were purposively selected to study brand attachment in the Malaysian context. Furthermore, it was deemed more appropriate at this juncture to use in-depth interviews in order to probe individuals' subjective experiences (Wimpenny \& Gass, 2000). This will enable the understanding of subjective meanings of consumers' lived experiences with brands.

\section{Research Objective}

This exploratory study was conducted among a small selected cross section of Malaysian consumers to investigate their attachment towards a brand of their choice. As literature on brand attachment in Malaysia is scarce, this study will assist marketers and brand managers when marketing their brands in Malaysia.

Hence, the objectives of the study were to (i) determine the antecedents of brand attachment, and (ii) describe the consequences of attachment among a cross section of Malaysian consumers.

\section{Methodology}

The antecedents of brand attachment and its consequences provide a conceptual framework for the study. Deshpande's (1983) recommendation to use qualitative methods for relatively new constructs such as brand attachment is followed. In-depth interviews with five purposively selected individuals living in Kuala Lumpur, Malaysia constitute the primary data for this research. The participants were first interviewed for a total of 1 to 1.5 hours each. Follow up interviews were conducted till saturation was achieved. These individuals were recruited through word-of-mouth and using the author's personal network. According to Park et al. (2010), attachment is time dependent and reflects a more advanced stage of a relationship. Hence, the participants were selected from those who are in their late 30 s and 40 s to gain a rich insight of their attachment to a brand over the years. They are from a variety of occupations and none have any theoretical background knowledge of the brand attachment phenomenon being studied. In order to ensure anonymity, the participants are identified by pseudonyms throughout this paper. A brief background of the participants is shown in Table 1.

Table 1. Participants' background

\begin{tabular}{llll}
\hline Participant Pseudonym & Age & Gender & Profession \\
\hline Elsie & Late 40s & Female & University lecturer \\
Nora & Late 40s & Female & University lecturer \\
Rick & Late $30 \mathrm{~s}$ & Male & Finance Manager \\
Pam & Late 40s & Female & Senior Business Development Manager \\
Jane & Late $30 \mathrm{~s}$ & Female & Freelance Public Relations Practitioner \\
\hline
\end{tabular}

The participants were selected based on the following criteria:

a) They labeled themselves as being attached to a brand

b) They did not express any definitive purpose of being attached to a brand

c) They were willing to be interviewed and share their experience with the brand.

The sample size can be considered as appropriate to an explorative study using qualitative data collection techniques (Fournier, 1998; Thompson \& Haytko, 1997). In addition, this sample size ensured in-depth data concerning life worlds and brand attachment necessary for thick description as espoused by Erlandson et al. (1993) and Mick and Buhl (1992) in Fournier (1998). The participants were females with only one male 
respondent. Previous research by Sherrod (1989) as cited by Fournier (1998) showed that females exhibited more and stronger interpersonal relationships and brand involvements.

The interviews consisted of unstructured and open-ended questions to gain first-person description of the participant's specific experience with a brand. The interview protocol questions were adopted and modified based on the questionnaire prepared by Park et al. (2010) and the review paper on brand attachment by Park et al. (2006a). All interviews were conducted either at the participants' offices or homes and audio recorded with their consent. The interview protocol included questions about participants' backgrounds and brands they believed they are attached to. Probing was extensively used to elicit a rich understanding on the participants' attachment towards the brand. The interviews were conducted solely by the author to permit the holistic perspective sought through this technique. In line with Fournier (1998), the interview was designed to obtain first person descriptions of the participant's brand usage history and contextual details concerning the participant's life world. Stories describing the genesis, evolution and usage of the brand were elicited. The author did not impose any constraints on the elicitation. Brands in this study were identified by the participants and included both goods and service brands. In order to stimulate and encourage discussion, the participants were in contact with the goods brand during the interview. Given the nature of service brands, the interviews were not able to be conducted close to the service provider. The goods brand involved in this study included a leading mobile phone brand and two renowned skin care brands while a holiday resort and hair salon brands represented the service brands.

In order to strengthen the trustworthiness of this study, member checks were conducted. This was to ensure credibility of the author's interpretation and understanding against the views shared by the participants. The interview transcripts were provided to the participants for their feedback and comments. A colleague reviewed the interview transcripts and interpretive summaries in a peer debriefing process. These procedures resulted in reanalysis of the data on several occasions. Triangulation of multiple stories from the same participant, of interviews conducted with the same participants at different points in time and of concepts reflected in brand attachment stories lent further credence to the credibility of the results. In addition to the thick description offered below, the purposive sampling of participants possessing uniquely different experiences and understanding of the phenomena allows for transferability judgments of the insights obtained. These are in line with suggestions made by Fournier (1998) on the issues of trustworthiness and credibility.

The interview produced rich textual data which was transcribed by the author for analysis. The textual data were analysed following guidelines set by Lincoln and Guba (1985). As a result of the iterative process, data were organized into similar categories from which themes were developed. Table 2 presents an example on the development of the theme 'achieving self and social goals'.

Table 2. Achieving self and social goals theme

\begin{tabular}{lll}
\hline Units of relevant meaning: & & \\
\hline Self-extension & Preference self & Happiness \\
Image of self & Personality-self & Feel good \\
Self-indulgence & Keeps me young & Excited when receiving \\
Self-pampering & Can relate a lot to this brand & information on the brand \\
Makes me more confident & Very big part of me & Glad when close to the brand \\
Meets my need & Works for me & Feel different \\
Very much part of me & Suits me well & Feeling special \\
Feel young & Something inside of me that I didn't & Grew on me \\
Look pretty & want to change & Maintains my youth \\
Look good & Positive external comments & Connection with others \\
\hline
\end{tabular}

Moustakas's (1994) suggestion on following four stages in phenomenological research namely "epoche" or suspension of researcher's preconceptions, phenomenological reduction, generating structural meanings from textural description and synthesis guided this study. Phenomenological reduction was accomplished through the creation of rich, accurate and complete accounts of the phenomenon. These included relationships with the brand, 
strong connection with the brand and other significant elements of the participants' experience. Coding of each transcript and constant comparison of data were completed to move to a composite description of attachment towards the brand. The coded transcripts were cross checked by a colleague.

\section{Findings}

Analysis of the data suggests that the participants have remarkably consistent views of brand attachment. The main themes causing brand attachment uncovered during the analysis were: achieving self and social goals, strong product and service characteristics, positive reminiscence and consumer expectations. A selected sample of the participants' comments that supports each theme is provided.

\subsection{Antecedent 1: Achieving Self and Social Goals}

This antecedent was derived from two sub-themes namely self and social goals. According to Fournier (1998), strong attachments form when brands help consumers achieve their self and social goals.

Elsie mentioned the following:

"The Motorola phones, most of it comes with a flip. I really like it. I like the feel of it. Surprisingly I got some very good comments from people who saw me using it. They said, "very nice phone, very small, it's very slim". I think I wanted to be different. Everybody was having a Nokia phone or a Sony Ericson. And I told myself, I've used this phone and it is so good. I wanted to be different. I want to carry a Motorola. People say carry a Blackberry. Why should I want to carry that brand? Although it is of a higher status than Motorola I want a Motorola".

This participant has been using this brand for the past 15-16 years. Motorola helped internalize and empower her core identity (Fournier, 1998). In Elsie's case brand attachment involved psychological appropriation of a specific brand, self-extension and a personal history between her and the brand. This is similar with the findings of Escalas (2004) and Fournier (1998).

Jane spoke on the following:

"It takes away the embarrass feeling. There are times in public, when I go out I always wear long pants.

With Jergens I apply it religiously every day and I started wearing shorts when I go shopping. Before that I wore long pants to cover my embarrassment. So it is just not healing. It healed my physical skin and also healed my emotions you know. It takes away the embarrassment".

Jane who has eczema since her schooling days is attached to Jergens as it heals her dry skin. Jane's work demands her to meet with customers regularly. Jergens enabled her to accomplish her social goals of better looking skin.

\subsection{Antecedent 2: Strong Product and Service Characteristics}

Brands that rely on strong products and service characteristics such as excellent service and product quality, product reliability and design will form the basis of attachment. This antecedent is in line with Lai et al. (2009) and Veloutsou and Moutinho (2009).

Jane verbalized the following:

"Jergens is really good, it works for me. It heals my skin. My hands and thumbs are dry. I feel so embarrass. Sometimes I will put my hands down and under the table. When I found Jergens lotion, if I use it a week in a row, the dryness wouldn't come back so fast. Jergens although an obscure brand here, is still the best for me".

"It is not a highly popular brand like (a leading lotion brand). It is an obscure brand. But it is the brand that I really like. So happened I tried and applied when I was working in an air-conditioned room while in Singapore. Wow! Finally I've found the one that is suitable for me. It may not be suitable for other people. But it is suitable for me. I'm overjoyed. It takes away that feeling of being trapped in the cycle of trying to look for the lotion that suits me and not being embarrassed when I go out with my friends. It is really embarrassing you know when the skin is so dry".

Jane has been relying on Jergens for the past 8 years. Jergens lotion helps solve her skin problem, thus resulting in strong attachment.

The strong attachment was also formed through differentiation and customer satisfaction. Rick narrated the following:

"I feel good. I feel like I'm overseas or somewhere because of the crowd. There are no locals. All of them 
are foreigners. I feel different. If you want a very good place to relax this is the place. I love this place. There are not so many Malaysians around. I feel special. Special in the sense that the moment I step in they know my name. Until the last day of your stay each member of their staff will know your name. There are not so many people and rooms. They call me Mr. Rick. I feel so great. It is so personal, which I cannot find in other resort hotels in Malaysia".

Rick has been returning back to the YTL Resorts in Malaysia for his local holidays for the past 9 years. As this resort group only caters to a niche high end market, a more personalized service is derived by Rick. Grisaffe and Nguyen (2011) posited that a brand must stand out from other options to engender attachment.

\subsection{Antecedent 3: Positive Reminiscence}

Schifferstein and Zwartkruis-Pelgrim's (2008) study found that enjoyment and memories contributed positively to the degree of attachment. They found that enjoyment might be the main reason for consumers to be attached to newly acquired objects while memories may be the primary reason for attachment to products owned for a long time.

Pam mentioned the following:

"I first started using Clarins to control my pimples problem. It helped to control that problem. As I got to know the brand, they had skin care, body care. After 1 year, my pimples disappeared and I realized this brand is not bad. I've been using it since then. 18 years ago I had so many pimples. Children ran away from me. Right now I feel very happy as people don't look at me that way. I don't feel embarrass now. I had so big pimples, then".

Clarins evoked good memories for Pam. Holbrook and Schindler (2003) explained that emotional attachments are form when brands evoke or symbolize nostalgic experiences or memories.

Elsie described her experience as follows:

"From a little girl, America has fascinated me. I grew up in a home where all the American cartoons, movies you name it. My uncle was a great fan of John F Kennedy \& that kind of thing. I'm very ingrained with that kind of concept. No matter who says bad things about America. Fine I know everybody has their weakness. But I for that brand anything. Motorola is from there. I think that could be one of the reason I like it because it is from there. It hadn't spread. Like Nokia it is all over the world. Motorola is equivalent to things like Apple maybe or Bill Gates, you know which is very unique there. Since they landed on the moon in 1969, it is like, I'm a fan. I really think that where science and technology is concern they are the forefront. And I love that feel from young, the way they produced their movies. It is fantastic and they probably go on to better things. So this is a reflection of that. Could be you know? I think it is for me. It is a reflection of something that I've always enjoyed".

Elsie's childhood memories of living with meaningful people (her uncle) who introduced her to all things American had a strong influence on her purchasing American made goods. These solidified her strong attachment towards a mobile phone brand which originates from the United States of America. According to Holbrook and Schindler (2003) consumers develop preferences at an early age and maintain them for the rest of their lives.

\subsection{Antecedent 4: Consumer Expectations}

Jergens met Jane's expectation by providing her a differentiated user experience. She feels unique. Jane explained the following:

"I actually do feel quite unique above the rest who know and use only the over commercialised brands. I feel

like I have a good secret product in my hands. I like it a lot because Jergens give me a differentiated user experience from other brands".

Rick also felt that the YTL Resorts provided the kind of holiday that he wants i.e. less crowd and an orderly environment as he mentioned it here:

"This is the thing that I want and appreciate when I go on holidays. There's no crowd. I don't have to rush for things. There are cultured people around. This is the kind of holiday that I want".

Consumer expectations are met through their satisfaction from using the brand and operational expectation (Fournier, 1998) as in the case of YTL Resorts. These resulted in the attachment towards the brands under study.

This study also derived six main themes of consequences towards brand attachment which are explained below: 


\subsection{Consequence 1: Commitment}

Park et al. (2006a) argued that commitment is an outcome of attachment in brand relationships. They further emphasized that it is a decision or pledge to maintain a long term relationship with a brand into the future.

Elsie commented the following with regards to her commitment towards Motorola:

"I have very positive thoughts regarding this brand. I have no thoughts of change. I just look forward to better technology that I'm sure will come with Motorola. I'm very sure".

Jane's commitment to Jergens is evidenced through her voicing the following:

"It suits me very well. I have been using this for years. I won't change until if they stop manufacturing it. I got no choice I will have to find the next best alternative. But as long as they are producing this brand I will continue using it. I won't change. If they came up with a face lotion tomorrow, I will try it too because of the success I received with this body lotion".

The participants expressed strongly their thoughts of not switching brands. In fact, they opined using future product extensions from their respective brands.

\subsection{Consequence 2: Sacrifice for the Brand}

Park et al. (2010) posited that consumers who are attached to a brand actively invest their own resources in the brand to maintain their brand relationship. Consumers will be willing to expend resources of their own such as financial and time resources.

Jane narrated the following experience:

"But at one point in time, I was searching in Mid Valley (shopping mall) \& all the pharmacies and failed to find it. I wanted to check online to see where it is distributed. The thought came but I didn't have the time. During lunch time near my office (in Kuala Lumpur) I checked out the nearby pharmacies for Jergens. When I can't find it, I concluded it was not sold here. I said all the more I should go to Singapore to purchase this brand".

Rick mentioned the following:

"There was one time when I needed to book for rooms at YTL's Cameron Highlands Resort for a family holiday and there wasn't enough rooms, we didn't go to other hotels. We waited till the rooms at YTL Cameron Highlands Resort were available and went on the holiday".

As a result of their strong attachment, the participants were willing to go through hardship to maintain their relationship with the brand. Jane promised herself to make a trip to Singapore in search for Jergens as she couldn't find it in Kuala Lumpur. Similarly, Rick was willing to delay his holidays at one of YTL's resorts until the rooms were available. The participants were also willing to pay a premium for their respective brands indicating their willingness to maintain the relationship at all costs.

\subsection{Consequence 3: Brand Advocate}

Consumers who are attached to brands will allocate their social resources such as defending the brand to others, Park et al. (2010).

Rick informed on the following:

"Yes certainly I will recommend (my friends or relatives) if they plan to go on a holiday at these destinations".

Nora who has been frequenting Mei Lan Saloon since her twenties strongly support the brand as evidenced in her mentioning the following:

"Mei Lan Saloon has done good to my hair all this while. As I frequent her shop, she knows my hair better and better. I have not been not that satisfied with Mei Lan Saloon's services. Yes, definitely I'll stand by this brand".

Jane's advocacy for Jergens is manifested in her articulating this:

"When I recommend it to whoever (like my sister and my husband), I said it with full conviction because I really do trust this brand".

With their strong brand attachment, these participants talked highly of their respective brands. They became the unofficial spokesperson for the brand. Positive word-of-mouth and recommendation to use the brand were conveyed to their spouse, relatives and friends. They even took it upon themselves to defend the brand should it 
be talked negatively by others.

\subsection{Consequence 4: Competing Brands are Secondary}

Elsie's view on competing brands:

"I don't think I've any negative ideas about other brands. I think, from what I know from people usually they are very good. They have the same features or maybe more. It is just that I wouldn't get them at this point of time as Motorola is still available".

Nora who has been frequenting Mei Lan Saloon for the past 20 years, felt the following:

"Mei Lan Saloon has put my perception on hair styling very high. And when I make comparisons with other hair salons, the rest are not as good".

Jane who found Jergens to be a solution to her skin problem, opined the following:

"I'm not so into commercials of other lotion. It didn't attract me. I found this brand already".

When it came to commercials or advertisements on competing brands, the participants were generally not interested. They will not consider other brands. However, when it came to their respective brands, they will take time to know and understand the advertisements.

When consumers are strongly attached to a brand, competing brands will be less prominent and be less likely to be regarded as substitutes (Park et al. 2010). The participants though are attached to their respective brands generally will not talk down on competing brands. Nora however, felt that the other hair salons are not as good as Mei Lan Saloon. Johnson and Rusbult (1989), state that some consumers who attached themselves to a brand will derogate alternatives.

\subsection{Consequence 5: Automatic Brand Recollection}

When asked to what extent will their thoughts and feelings toward their respective brands come to mind so naturally during discussions of a particular product/service among their friends/relatives, the following were recorded from Rick, Elsie and Nora respectively:

"Automatically I will recall YTL Resort".

"When people are talking about phones, my thoughts will definitely go to Motorola. I will pitch in".

"Obviously I will think of Mei Lan Saloon when we are discussing of hair salons. That's the only hair salon I've been going to regularly. If they talk about curly hair, I'll tell them that Mei Lan Saloon does it good".

According to Park et al. (2006a), brand attachment reflects a consumer's strong self-brand linkages and automatic retrieval of thoughts and feelings about the brand.

\subsection{Consequence 6: Disappointment and Discontentment}

Nora spoke on the following:

"The thing is as of this year Mei Lan Saloon has ceased operations. The owner has moved somewhere else. I'm not getting the service from the saloon anymore. When I was informed that Mei Lan Saloon will be moving to another place I was quite disappointed. I was quite sad".

As Nora has strong dependency with this brand she was affected by the news of Mei Lan Saloon ceasing operations. All the other participants also mentioned that they would be disappointed should the brand fails on them or is no longer available.

Another respondent, Jane stated the following:

"If this brand has any misgivings or didn't function to what it was supposed to do, I will be very, very disappointed. If they improve, I'll forgive. There will be a slight mistrust. It must regain my confidence."

In Jane's case, she will be extremely disappointed if Jergens were to fail on her. She will have a slight mistrust on the brand and the brand will have to improve in order to win her confidence.

Park et al. (2010) explained that separation from an attachment object creates emotional distress and the loss of possession is also mourned.

\section{Discussion}

In investigating the underlying reasons, the participants showed evidence that achieving their self and social goals, the strong product and service characteristics, their positive reminiscence and the brand meeting their expectations attributed towards their brand attachment. First, this research confirms current literature regarding 
achievement of self and social goals as a cause for brand attachment (Fournier, 1998). Next, the study is in alignment with the findings of Grisaffe and Nguyen (2011) with regards to the three other antecedents discussed.

The participants in this study are simply not buying the brands because they like it or because it is affordable. The brands offer a relationship experience that adds meaning to their lives. For Jane and Pam, their attachment towards Jergens and Clarins respectively are due to their skins condition. Jergens and Clarins helped them to feel more confident in public as it solved Jane's eczema problem and Pam's pimples. They could go about in public without feeling embarrass. Nora who's attached to her hair salon for the past 20 years felt that Mei Lan Saloon gave her the confidence of looking better after each visit. In Elsie's case, the Motorola hand phone added a psychosocial meaning to her life. She wanted to be different from the rest who were using the more common hand phone brands. Similarly for Rick the YTL Resorts brand made him felt that he belongs to a different social class whenever he stayed at these resorts.

In analyzing the participants' stories, it appeared that they are all experiencing excellent product and service quality from the attached brands which surpasses that of competing brands. Jergens and Clarins provided the solution to the participants after many trials with different brands. Mei Lan Saloon gave Nora quality hair-cuts that meets her curly hair needs. For Elsie, it was Motorola's durability and style. Rick on the other hand experienced a differentiated and unique service offering from YTL Resorts that form the basis of his attachment.

The brands identified by the participants brought emotional meanings into their lives. Elsie was able to trace back her affinity with American goods for her current attachment towards Motorola. The fond memories of using the brand for the very first time set a strong foundation for the rest of the participants to form an attachment towards the brands discussed. It is evident that these pleasant memories and experiences with the brands solidified their attachment.

The participants' experiences also showed that their expectation and the subsequent performance of the brands led them towards attaching themselves to these brands. Each of these brands gave a differentiated user experience to them. The participants narrated that they felt unique and different when using these brands.

Consequently, being attached to a brand resulted in them having a commitment to maintain the relationship into the future and at all costs. In addition, they explained their willingness to make sacrifices for the brand. Next, the study found that the participants will advocate positive word-of-mouth and defend the brand. According to Park, MacInnis and Priester (2006b), by publicly displaying, defending, advocating, or promoting their support and making sacrifices in terms of time, money and energy for a brand shows the more strongly attached the participants are towards the brands.

Given their attachment, competing brands are perceived to be not important resulting in advertisements by competing brands having no effect on the participants. These participants could easily recall their brand names as it comes naturally to them during discussions. However, when the brands do not meet their expectations or is no longer available they will be disappointed and discontented.

The results from the present study indicate that marketers must ensure that each contact point with the consumer must be able to provide a memorable and pleasurable experience. It is evident from this study that memories from the past or when the consumer was using the brand when they were younger had a great impact on how they perceive the brand today. With the proliferation of social media today, the consumers of tomorrow will have greater and stronger memories of their first taste with a particular brand.

\section{Limitation and Future Research}

As only qualitative data was collected, the findings can be seen as limited in its ability to be generalized. However, the understanding of the phenomenon from the lived experiences of the participants will enrich the field of brand attachment research. The antecedents and consequences of brand attachment derived from this study can be further tested in a quantitative survey.

The study was conducted among participants in their late 30 s to late 40 s. A richer insight could perhaps be gained if older consumers i.e. those aged 50 and above and younger consumers i.e. those aged 30 and below are included in the study. It would be interesting to investigate their reasons to being attached to brands other than those mentioned in this study. The views of Malaysians from various other parts of the country will surely add depth in determining the essence of this phenomenon.

Certainly a sequential quantitative study on the antecedents developed from this study will be beneficial. It will further add value to the brand attachment literature if strong and weak antecedents could be identified. A study on the relationship of these antecedents and its effect on a brand's profitability will further extend the body of knowledge on brand attachment. 
Future research could pre-determine a common brand (eg. Coca-Cola) rather than consumers' own self-selection as in the case here. This will allow for a study on a constant brand across all emotional attachment conditions.

The participants in this study recalled their experience with the brand based on their memories. This could be subjected to memory errors and biases. To circumvent this, a longitudinal study could be undertaken to investigate how brand attachment develops.

\section{Conclusion}

Generally the article has attempted to contribute further to the existing literature on both goods and service brand attachment from an Asian perspective. Additionally, it also addresses the consequences of brand attachment. Thus, this understanding will enable brand managers to be aware of the need to establish strong rapport with potential consumers at every contact point.

The findings from this study will enable marketers to further understand the reasons behind consumers' strong attachment towards a brand, which is still an under-research area. This knowledge will provide an insight for existing and new brands that intend to penetrate into the Malaysian market. The understanding of the respondents' attachment will also be beneficial to determine how this will have a bearing on the brand and competing brands.

Brand managers could formulate appropriate marketing strategies targeting consumers who are attached to their brands. This is important in order to maintain and/or strengthen the attachment. A one-to-one marketing rather than mass marketing suits well for these consumers. This certainly will make these consumers feel special and unique. Consumers, who feel very strongly for their brands, could be roped in as brand ambassadors or the brand's spokesperson. It will be more assuring for existing and prospective consumers to hear about the brand's features and benefits from another consumer who strongly advocates the brand. With their positive word-of-mouth they could play an important role in converting skeptics of a particular brand into potential consumers.

It is worth noting that the first contact the consumer has with the brand is crucial. These experiences with using or being associated with the brand will subsequently sow the seeds of attachment towards the brand. Hence, marketers must continuously ensure consistent delivery of its marketing communications effort. They should also realize that consumers are attached to a particular brand because it adds meaning to their lives. For brands to be meaningful in the consumers' lives it has to be unique, an extension of the consumers' identity and most importantly meets the social goals of the consumer.

In order to strengthen the emotional ties between the consumer and the brand, brand managers need to pursue experiential marketing activities. Schmitt (1999) explained that these experiences replace functional value by providing sensory, emotional, cognitive, behavioral and relational values. By promoting events and activities that touches on the consumers' emotions and senses, these will help build the foundation of love and subsequently attachment towards the brand.

As consumers have developed an attachment towards their brands, manufacturers must be cautious when making any modification towards the product under a particular brand name. Consumers who are attached to a brand may be discontented and disappointed if the brand had any misgivings or didn't function appropriately as indicated by the respondents. This will subsequently lead to mistrust of the brand. Changes to the product without careful thought may have dire consequences on the consumers' attachment towards the brand.

Consumers are emotional beings. The key to marketing success is the understanding of how and why they form attachment to brands. This research was conducted in the true spirit of uncovering the causes of brand attachment among Malaysian consumers, an under-research area. The findings discussed in this article have provided rich subjective meanings of consumers' lived experiences with their five brands. The contribution of the qualitative findings from this study complements the existing quantitative researches on brand attachment.

\section{Acknowledgements}

The author wishes to thank Associate Professor Dr. Esther Daniel for her invaluable comments in the writing of this article.

\section{References}

Ainsworth, M. D. S., \& Bowlby, J. (1991). An ethological approach to personality development. American Psychologist, 46, 331-341. http://dx.doi.org/10.1037/0003-066X.46.4.333

Berman, W. H., \& Sperling, M. B. (1994). The structure and function of adult attachment. In W. H. Berman, \& M. B. Sperling (Eds.), Attachment in adult: Clinical and developmental perspectives (pp. 3-28). New York: 
Guilford.

Deshpande, R. (1983). Paradigms lost: on theory and method in research in marketing. The Journal of Marketing, 47(4), 101-110. http://dx.doi.org/10.2307/1251403

Escalas, J. E. (2004). Narrative processing: building consumer connections to brands. Journal of Consumer Psychology, 14(1-2), 168-180. http://dx.doi.org/10.1207/s15327663jcp1401\&2_19

Fournier, S. (1998). Consumers and their brands: developing relationship theory in consumer research. Journal of Consumer Research, 24(4), 343-373. http://dx.doi.org/10.1086/209515

Grisaffe, D. B., \& Nguyen, H. P. (2011). Antecedents of emotional attachment to brands. Journal of Business Research, 64, 1052-1059. http://dx.doi.org/10.1016/j.jbusres.2010.11.002

Holbrook, M. B., \& Schindler, R. M. (2003). Nostalgic bonding: exploring the role of nostalgia in the consumption experience. Journal of Consumer Behaviour, 3(2), 107-127. http://dx.doi.org/ 10.1002/cb.127

Jahn, S., Gaus, H., \& Kiessling, T. (2012). Trust, commitment, and older women: exploring brand attachment differences in the elderly segment. Psychology and Marketing, 29(6), 445-457. http://dx.doi.org/10.1002/mar.20533

Johnson, D. J., \& Rusbult, C. E. (1989). Resisting temptation: devaluation of alternative partners as a means of maintaining commitment in close relationships. Journal of Personality and Social Psychology, 57(6), 967-980. http://dx.doi.org/10.1037/0022-3514.57.6.967

Lai, F., Griffin, M., \& Babin, B. J. (2009). How quality, value, image and satisfaction create loyalty at a Chinese telecom. Journal of Business Research, 62(10), 980-986. http://dx.doi.org/10.1016/j.jbusres.2008.10.015

Lambert-Pandraud, R., \& Laurent, G. (2010). Why do older consumers buy older brands? The role of attachment and declining innovativeness. Journal of Marketing, 74(July), 104-121. http://dx.doi.org/10.1509/jmkg.74.5.104

Lincoln, Y. S., \& Guba, E. G. (1985). Naturalistic Inquiry. Sage Publications, Newbury Park, CA.

Marshall, M. N. (1996). Sampling for qualitative research. Family Practice, 13(6), $522-525$. http://dx.doi.org/10.1093/fampra/13.6.522

Moustakas, C. (1994). Phenomenological research methods. Sage Publications, Thousand Oaks, CA.

Park, C. W., MacInnis, D. J., \& Priester, J. (2006a). Brand attachment: constructs, consequences and causes. Foundations and Trends in Marketing, 1(3), 191-230. http://dx.doi.org/10.1561/1700000006

Park, C. W., MacInnis, D. J., \& Priester, J. (2006b). Beyond attitudes: attachment consumer behavior. Seoul Journal of Business, 12(2), 1-34.

Park, C. W., MacInnis, D. J., Priester, J., Eisingerich, A. B., \& Iacobucci, D. (2010). Brand Attachment and Brand Attitude Strength:Conceptual and Empirical Differentiation of Two Critical Brand Equity Drivers. Journal of Marketing, 74(November), 1-17. http://dx.doi.org/10.1509/jmkg.74.6.1

Schifferstein, H. N. J., \& Zwartkruis-Pelgrim, E. P. H. (2008). Consumer-Product Attachment: Measurement and Design Implications. International Journal of Design, 2(3), 1-14.

Schmitt, B. (1999). Experiential Marketing. Journal of Marketing Management, 15(1-3), 53-67. http://dx.doi.org/10.1362/026725799784870496

Thompson, C. J., \& Haytko, D. L. (1997). Speaking of Fashion: Consumers' Uses of Fashion Discourses and the Appropriation of Countervailing Cultural Meanings. The Journal of Consumer Research, 24(1), 15-42. http://dx.doi.org/10.1086/209491

Thomson, M., MacInnis, D. J., \& Park, C. W. (2005). The ties that bind: Measuring the strength of consumers' emotional attachments to brands. Journal of Consumer Psychology, 15(1), $77-91$. http://dx.doi.org/10.1207/s15327663jcp1501_10

Veloutsou, C., \& Moutinho, L. (2009). Brand relationships through brand reputation and brand tribalism. Journal of Business Research, 62(3), 314-322. http://dx.doi.org/10.1016/j.jbusres.2008.05.010

Wimpenny, P., \& Gass, J. (2000). Interviewing in phenomenology and grounded theory: Is there a difference? Journal of Advance Nursing, 31(6), 1485-1492. http://dx.doi.org/10.1046/j.1365-2648.2000.01431.x 